\title{
Kajian Model Desa Cerdas (Smart Village) berbasis Satu Desa Satu Greenhouse pada Wilayah Pusat Pertumbuhan Desa di Kabupaten Konawe
}

\author{
${ }^{1}$ Welis Raldianingrat dan ${ }^{2}$ Fitria \\ ${ }^{1}$ Universitas Lakidende Unaaha \\ ${ }^{2}$ Universitas Lakidende Unaaha \\ Correspondence email:welisraldianingrat89@gmail.com
}

\begin{abstract}
Abstrak: Penelitian ini bertujuan untuk merancang fungsi dan desain rumah kaca dan sistem kontrol untuk manfaat yang diperoleh dari sistem pertanian tertutup. Menganalisis model perancangan Desa yang dapat menghasilkan capital gain berupa aliran modal masuk sebagai turunan dari penerapan konsep One Village One Greenhouse. Menganalisis sistem kelembagaan Desa dalam desain Desa Berbasis Produksi. Analisis ini menggunakan analisis deskriptif kuantitatif dengan menggunakan sampel lokasi desa di Kecamatan Oneembute. Penelitian ini akan menyajikan kerangka isi penelitian tentang hubungan dan pengaruh variabel yang diteliti (input) dengan variabel output. Teknik pengumpulan data adalah (1) observasi (2) wawancara mendalam (deep interview), dan (3) penelusuran kepustakaan. Hasil penelitian menunjukkan bahwa 1) Desain rumah kaca berupa terowongan dengan sistem klem memberikan keunggulan dari segi kekuatan struktur dengan tingkat pembuatan yang mudah dilakukan oleh siapa saja. Perancangan rumah kaca sistem terowongan mampu memberikan kemudahan dalam pengendalian suhu udara sehingga berdampak positif terhadap pengendalian produksi tanaman khususnya di wilayah Kecamatan Oneembute, 2) Hasil perbandingan manfaat ekonomi berupa produksi dan biaya analisis sensitivitas menunjukkan bahwa hasil NPV adalah Rp. 326.545.587,- yang berarti usahatani ini akan memperoleh keuntungan sebesar Rp.326.545.587,- selama 5 tahun sesuai dengan present time value of money dengan asumsi skenario rendah, yang berarti usahatani dilakukan tanpa teknologi Greenhouse. Sedangkan hasil analisis sensitivitas skenario produksi dan biaya tinggi menunjukkan hasil NPV sebesar Rp. 476.887.391,- yang artinya usaha tani ini akan memperoleh keuntungan sebesar Rp. 476.887.391,- hanya dalam waktu 1 tahun sesuai dengan time value of money sekarang dengan asumsi pertanian dilakukan dengan menggunakan teknologi Greenhouse, 3 ) Model kebijakan yang dapat diterapkan untuk mendukung kebijakan Desa Pintar berbasis satu desa satu rumah kaca di Kecamatan Oneembute merupakan model kebijakan elit dimana Kepala Desa memiliki kewenangan untuk mengambil keputusan investasi rumah kaca untuk usaha produktif dan kreatif pedesaan.
\end{abstract}

Kata kunci: Teknologi Rumah Kaca; Arus Masuk Modal; Desa Pintar

\begin{abstract}
This study aims to design the function and design of greenhouses and control systems for the benefits obtained from closed farming systems. Analyzing the Village design model that can generate capital gains in the form of capital inflows as a derivative of the application of the One Village One Greenhouse concept. Analyzing the Village institutional system in Production-based Village design. This analysis uses a quantitative descriptive analysis using a sample of village locations in Oneembute District. This study will present a framework of research content about the relationship and influence of the variables studied (input) with the output variable. Data collection techniques are (1) observation (2) in-depth interviews (deep interviews), and (3) literature searches. The results of the study show that 1) Greenhouse design in the form of a tunnel with a clamping system provides advantages in terms of structural strength with a level of manufacture that is easy to do by anyone. The tunnel system greenhouse design is able to provide convenience in controlling air temperature so that it has a positive impact on plant production control, especially in the Oneembute District area, 2) The results of the comparison of economic benefits in the form of production and cost sensitivity analysis show that the NPV result is Rp. 326.545.587,- which means this farm will receive a profit of Rp.326.545.587,- for 5 years according to the present time value of money with the assumption of a low scenario, which means that farming is done without Greenhouse technology. Meanwhile, the results of the sensitivity analysis of the high production and cost scenarios show that the NPV result is Rp. 476,887,391, - which means this farming business will receive a profit of Rp. 476,887,391,- in just 1 year according to the time value of money now with the assumption that farming is done using Greenhouse technology, 3) The policy model that can be applied to support the Smart Village policy based on one village one greenhouse in Oneembute District is an elite policy model where The Village Head has the authority to make greenhouse investment decisions for rural productive and creative businesses.
\end{abstract}

Keywords: Teknologi Greenhouse; Capital Inflow; Smart Village 
Welis Raldianingrat dan Fitria, Kajian Model Desa Cerdas (Smart Village) berbasis Satu Desa Satu Greenhouse pada Wilayah Pusat Pertumbuhan Desa di Kabupaten Konawe

\section{PENDAHULUAN}

Kabupaten Konawe merupakan salah satu kabupaten di Provinsi Sulawesi Tenggara yang cukup potensial membangun greenhouse karena potensi pembangunan di sector pertanian dan pengembangan usaha yang cukup memadai. Pemerintah Kabupaten Konawe melalui kerjasama dengan lembaga-lembaga yang ada di Kabupaten Konawe diantaranya lembaga pemasaran, UKM dan Penyuluh Pertanian Lapangan (PPL) guna mewujudkan pembangunan dan mengembangkan potensi yang ada di Kabupaten Konawe khusunya pembangunan pertanian yang lebih unggul.

Kabupaten Konawe terdiri dari 297 Desa yang menempati 28 Kecamatan. Menurut data statistic tahun 2018 bahwa terdapat 297 Desa yang sangat potensial dalam pengembangan pertanian, dimana letak desa tersebut berada di wilayah dataran. Data tersebut menunjukkan bahwa sumber daya pertanian menjadi factor utama dalam pembangunan di Kabupaten Konawe. Hal tersebut sejalan dengan program pembangunan pemerintah yang dicanangkan melalui visi "membangun dari pinggir" yang berarti membangun dari Desa.

Konsep membangun dari Desa telah dicanangkan oleh Pemerintah dan swasta dengan berbagai pendekatan. Bahkan beberapa penelitian telah di introduksi dengan ciri khas Desa masing-masing. Banyaknya sumber daya di Desa mengakibatkatkan menguatnya inovasi Desa sebagai tools (alat bantu) memperkuat dan meningkatkan pertumbuhan ekonomi Desa. Beberapa contoh misalnya penerapan teknologi informasi guna menghubungkan sumber daya pedesaan dengan market (pasar global) melalui digital transformasion yang dikenal dengan istilah "Smart village" yang merupakan transformasi dari "Smart City". Tidak cukup hanya itu sumber daya pedesaan juga ditingkatkan dengan concern pada produk tertentu dengan program "One Village One Product" atau OVOP yang mula-mula dikembangkan di Negara Jepang dan telah sukses diberbagai Desa di Indonesia terutama wilayah Jawa. Maka adaptasi berlanjut dengan tema inovasi selanjutnya seperti Desa Wisata, Desa Mandiri dan lain sebagainya.

Meskipun demikian tidak semua program pembangunan Desa tersebut membawa keberhasilan di Desa lainnya di Indonesia terutama di Kawasan Timur. Seperti yang disebutkan dalam data statistic diatas bahwa sekitar $80 \%$ wilayah di Kabupaten Konawe (wilayah pedesaan) berpotensi Pertanian. Namun belum ada satupun konsep pengembangan yang dapat mendorong pertumbuhan yang ditandai dengan income perkapita Desa yang jika dirata-rata kan jumlah penduduknya mampu setara dengan Upah Minimum Regional (UMR). Maka dari itu perlu adaptasi tau alih teknologi dalam upaya mendorong peningkatan produksi di Desa.

Terdapat pendekatan lain dalam pengembangan pedesaan yakni pengembangan Agropolitan yang merupakan sebuah pendekatan pengembangan Kawasan pertanian pedesaan. Hal tersebut dicanangkan dengan maksud menyeimbangkan pembangunan antara Desa dan Kota dimana terjadi kesenjangan yang melebar. Dengan kata lain pengembangan agropolitan merupakan suatu upaya memperpendek jarak antara masyarakat di Kawasan sentra pertanian dengan pusat-pusat pelayanan konvensional. Konsep tersebut sejalan dengan UU No 26 Tahun 2007 tentang penataan ruang disebutkan bahwa Kawasan agropolitan adalah Kawasan yang terdiri atas satu atau lebih pusat kegiatan pada wilayah pedesaan.

Guna mendukung tumbuhnya pusat pertumbuhan Kawasan agropolitan maka diperlukan adaptasi teknologi. Salah satu teknologi yang dapat mendorong produksi di pedesaan adalah mengembangkan program "Satu Desa Satu Greenhouse", yang pengelolaannya di canangkan oleh Pemerintah mulai dari Kabupaten Hingga Pemerintah Desa dengan manajemen quardraple helix yakni sinergi pembangunan antara Pemerintah, Masyarakat (Petani), Pendidikan, dan Pengusaha (Business). Maka penelitian ini dikembangkan dengan tema "Model Desa Cerdas (Smart Village) berbasis Satu Desa Satu Greenhouse pada Pusat Pertumbuhan Desa di Kabupaten Konawe". 
Welis Raldianingrat dan Fitria, Kajian Model Desa Cerdas (Smart Village) berbasis Satu Desa Satu Greenhouse pada Wilayah Pusat Pertumbuhan Desa di Kabupaten Konawe

\section{LANDASAN TEORI}

Desa merupakan bagian terdepan dalam menentukan suatu arah kebijakan dalam rangka pembangunan nasional. Dengan demikian pemerintah memiliki tanggungjawab untuk mengangkat area pedesaan menjadi titik akselerasi dalam pembangunan manusia, infrasturktur, ekonomi, budaya, maupun sosialnya.

Smart Village merupakan suatu konsep tentang desa pintar yang mengadopsi komponen dan indikator yang terdapat pada konsep smart city atau kota pintar. Namun pengadopsian ini disesuaikan dengan permasalahan yang ada di pedesaan sehingga skala dalam pelaksanaannya lebih kecil dibandingkan dengan perkotaan yang bertujuan untuk menyelenggarakan pemerintahan dan pelayanan diberbagai bidang dengan mengikut sertakan teknologi didalamnya.

Dalam pengembangannya, konsep Desa Cerdas Mengadopsi dari Konsep Kota Cerdas, namun mengadopsian ini disesuaikan kondisi dan permasalahan yang terdapat di area desa, Berikut adalah dimensi yang terdapat di dalam konsep Kota Cerdas (Santoso dkk:19) :

Gambar 1 : Dimensi Smart City (Dalam Santoso dkk, 2019)

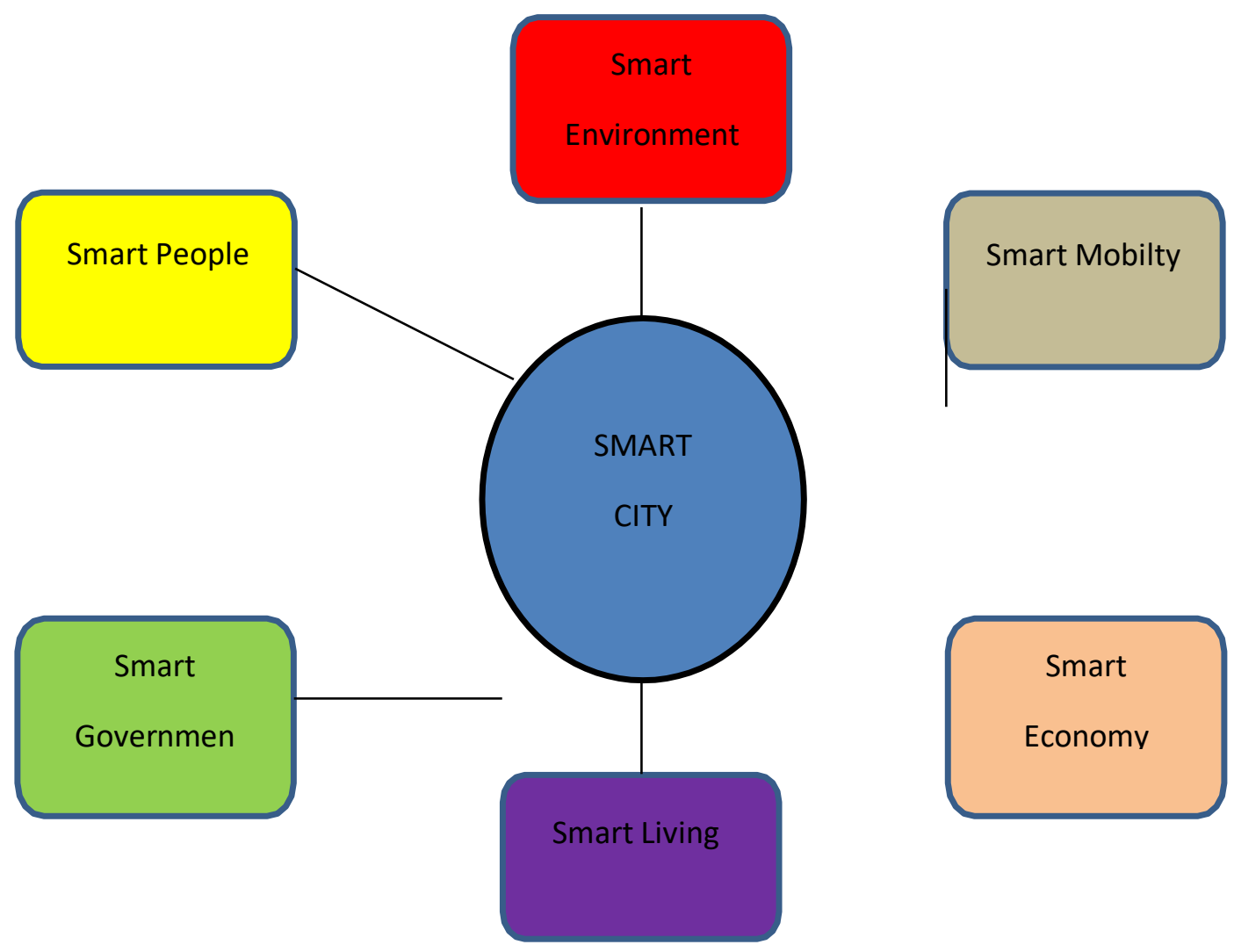

Beberapa karakteristik dalam komponen kota cerdas dapat diadopsi ke dalam konteks desa seperti smart governance, smart economy, smart mobility, smart environment, smart people, smart living, dan yang sedang menjadi diskusi hangat baru-baru ini, smart tourism. Adopsi konsep dan karakteristik kota cerdas ke desa cerdas dalam kerangka pemanfaatan TIK menyelesaikan berbagai permasalahan publik yang kebanyakan akan memberikan pengaruh pada sektor ekonomi, politik, pendidikan, sosial, dan aktivitas kebudayaan (Kitchin, 2014; Carrasco-Sáez dkk., 2017; Visvizi dkk., 2018, Lytras dkk., 2018 dalam Santoso dkk, 2019:12).

Dalam konteks smart village, adanya pemanfaatan teknologi informasi dapat memberikan peningkatan pelayanan kepada masyarakat, pemerintah desa akan dapat menyelenggarakan fungsi 
Welis Raldianingrat dan Fitria, Kajian Model Desa Cerdas (Smart Village) berbasis Satu Desa Satu Greenhouse pada Wilayah Pusat Pertumbuhan Desa di Kabupaten Konawe

pemerintahan secara efektif dan transparan kepada masyarakat. Selain itu, pemanfaatan teknologi informasi secara umum dapat meningkatkan kinerja dan produktivitas pemerintah desa. Pembangunandesa menjadi bagian tidak terpisahkan dalam penyelenggaraan fungsi pemerintah desa. Sejak diberlakukannya Undang-Undang Nomor 6 Tahun 2014 tentang Desa telah terjadi reposisi kewenangan penyelenggaraan pembangunan dari pemerintah daerah ke pemerintah desa. Dalam proses pembangunan desa, pemanfaatan teknologi informasi menjadi penting dan menjadi bagian dalam mendorong keberhasilan pembangunan desa. Teknologi informasi menjadi alat selain untuk mempermudah proses penyusunan dan pelaksanaan pembangunan desa, juga menjadi media untuk mempertemukan berbagai pemangku kepentingan dalam pembangunan desa. Teknologi informasi mempertemukan berbagai kepentingan untuk bisa dirumuskan secara bersama-sama menjadi sebuah kebijakan pembangunan desa (Dian Herdiana, 2019:8).

\section{METODE}

Jenis penelitian ini adalah deskriptif kuantitatif. Pendekatan yang digunakan adalah penelitian kuantitatif (quantitative research) yang merupakan metode untuk mengeksplorasi dan memahami secara jelas dengan mendiskripsikan profil wilayah lokasi studi, kondisi perekonomian masyarakat Desa, rancangan greenhouse dan pendekatan kuantitatif yang menganalisa kelayakan investasi, system zonasi Kawasan pengembangan terintegrasi dengan RT RW, system kelembagaan masyarakat dan pengelolaan Desa. Teknik analisis deskriptif kuantitatif pada penelitian ini aspek yang digunakan adalah aspek finansial, digunakan untuk melihat usaha tersebut layak atau tidak untuk dijalankan dengan memperhatikan aspek finansialnya.

\section{HASIL DAN PEMBAHASAN}

\section{Konsep Pengembangan Teknologi Greenhouse pada Tanaman Pangan}

Pengembangan teknologi Greenhouse pada tanaman pangan telah berkembang seiring dengan perkembangan teknologi bidang Pertanian. Tujuan yang mengarah pada alas an pengembangan teknologi Greenhouse adalah untuk dapat melakukan control terhadap produksi. Paradigma tentang fungsi greenhouse bagi tanaman pangan sebagai sarana untuk mengurangi dampak serangan hama/penyakit pada tanaman serta dampak cuaca mulai mengalami pergeseran kearah control produksi meskipun didalamnya masih terdapat usaha penanggulangan penyakit/hama dan kendali cuaca terhadap tanaman.

Berbagai tipe greenhouse dikembangkan berdasarkan kondisi geografis wilayah pengembangannya. Akan tetapi tidak seluruh tipe greenhouse mampu beradaptasi dengan lingkungan sekitar terutama pada pemberian nutrisi suhu bagi tanaman. Secara umum tipe greenhouse terdiri dari :

1. Tipe Tunnel

Green house tipe tunnel berbentuk seperti lorong setengah lingkaran. Atap yang melengkung sangat efektif menghindari kerasnya terpaan angin. Struktur kerangka di buat dari pipa besi yang kuat. Tipe tunnel ini tidak cocok untuk struktur dari kayu, karena untuk menciptakan lengkungan sangatlah sulit. Tipe ini banyak di gunakan di daerah sub tropis yang sangat efektif pada musim dingin.

2. TipePigy back

Green house type piggy back paling banyak di gunakan di daerah tropis dengan banyak jendela pada atapnya untuk ventilasi sebagai pertukaran udara dan mempertahankan suhu dan kelembaban udara. Type ini sering disebut tropical green house. Pada daerah yang memiliki tiupan angin yang kencang type ini tidak disarankan.

3. Tipe Multi Span

Green house type ini merupakan campuran dari tipe tunnel dengan tipe piggy back. Karena itu, maka tipe green house ini mempunyai kelebihan dari tipe tunnel dan tipe piggy back, yaitu strukturnya kuat namun tetap memiliki ventilasi yang maksimal.Masing-masingtipe greenhouse tersebutmemilikikeunggulan dan kelemahan dan sangatbergantung pada kondisigeografis dan iklimmasing-masing wilayah. 
Welis Raldianingrat dan Fitria, Kajian Model Desa Cerdas (Smart Village) berbasis Satu Desa Satu Greenhouse pada Wilayah Pusat Pertumbuhan Desa di Kabupaten Konawe

\section{Analisis kondisi lingkungan Kecamatan Onembute Kabupaten Konawe untuk pengembangan Teknologi Greenhouse}

Kabupaten Konawe memiliki kondisi geografis yang bervariasi dari pegunungan, perbukitan hingga dataran terkombinasi menjadi satu wilayah dataran Kecamatan Onembute. Selain itu iklim tropis yang tidak jauh berbeda dengan umumnya iklim tropis di Indonesia khususnya di wilayah Provinsi Sulawesi Tenggara.

Kebutuhan analisis kondisi lingkungan dalam pengembangan teknologi Greenhouse maka dalam penelitian ini menggunakan tiga kategori kondisi lingkungan yakni kondisi geografis dan kondisi iklim (cuaca) dan kategoriAngin.

\section{PengembanganTeknologi Greenhouse mendukungpembangunanDesa}

Penentuan kelayakan bangunan dapatdiketahui dengan analisis yang dilakukanpada setiap struktur bangunan berdasarkansifat fisik dan mekanik bahan. Tahapananalisis struktur diawali dengan melakukanidentifikasi karakteristik bahan, pengukurandimensi, serta melakukan analisis mengenaipembebanan yang terjadi dan evaluasikekuatan struktur bangunan.

Bangunan greenhouse penelitian inimerupakan greenhouse dengan tipe atapmodified Tunnel yang dilengkapidengan atap bukaan sebagai ruang ventilasi.Luasan total greenhouse mencapai $6 \mathrm{~m}$ x $55 \mathrm{~m}$ yang luas area nya $330 \mathrm{~m} 2$ dengan tinggi total bangunan sebesar 6,87 m. (Lihat pada Gambar).

Bangunangreenhouse sendiri terdiri dari 6 strukturutama, yaitu struktur atap, kasau, gording,kudakuda, dinding, kolom, dan pondasiyang setiap struktur tersebut ditinjauberdasarkan kekuatan dan ketahanannya.Struktur atap pada greenhouse penelitianini merupakan atap berbahan plastic film lembarandengan ketebalan 0,2 $\mathrm{mm}$ dan kemiringanatap mencapai 30,556 ${ }^{\circ}$. Menurut Widyastuti(1993), kemiringan atap tersebut tergolongoptimal dalam mengalirkan air hujan yangmengenai atap dan dalam mentransmisikanradiasi sinar matahari. Pembebanan yangterjadi pada atap didapat dari beban bahanpenutup atap dan beban angin yangdipengaruhi oleh kecepatan angin rancanganmaksimal sebesar 42,862 m/s. Beban atapatas dapat mencapai $2.767,8 \mathrm{~kg}$ dan $6.663,15 \mathrm{~kg}$ pada atap bawah. Pembebanan yangterjadi pada atap menyebabkan terjadinyategangan tarik pada tepi atap sebesar $1.404 \mathrm{~kg} / \mathrm{m}^{2}$ dan lendutan sebesar $0,002 \times 10^{-4}$ $\mathrm{mm}$.

Struktur kasau pada greenhouse berupa bingkai berbahan square tube untuksetiap bagian kecil bahan penutup atap.Pembebanan yang terjadi pada kasau atapatas sebesar 3.646,2 $\mathrm{kg}$ dan $8.770,8 \mathrm{~kg}$ padakasau atap bawah. Beban yang ditahan olehstruktur kasau ini menyebabkan terjadinyalendutan pada kasau pada arah horizontalsebesar $0,013 \times 10^{-4} \mathrm{~mm}$ dan $0,023 \times 10^{-4} \mathrm{~mm}$ pada arah vertikal.

Struktur rangka pada greenhouse menggunakan pipa galvanisukuran 1,5 inch Panjang $6 \mathrm{~m}$ disambung menggunakan pipe connection pin. Struktur batang menerus membentuk para bola setengah lingkaran adalah bentuk umum dari tipe tunnel. Bangunan greenhouse dilengkapi dengan bukaan pada sisi kiri dan kanan berfungsi sebagai sirkulasi udara yang dilengkapi dengan jarring pengaman.

Pembebanan pada bangunan greenhouse ditahan langsung oleh struktur utama (tunnel). Jumlah struktur utama 90 batang dengan jarak antara batang struktur tunnel $60 \mathrm{~cm}$. pembenanan masing-masing batang bersifat monolit dengan pembebanan total struktur utama dapat mencapai $35.082,3 \mathrm{~kg}$ yang kemudian didistribusikan secara merata kesemua struktur utama sebesar 389,80 kg per batang struktur. Keseluruhan pembebanan struktur greenhouse langsung disalurkan melalui tanah dengan system pondasi langsung dimana tanah berfungsi sebagai pondasi.

System pondasi langsung menggunakan kekuatan tanah menggunakan kekuatan batang horizontal yang diklem pada setiap batang struktur utama tunnel. Pembebanan pada pondasi langsung ini dapat menimbulkan tegangan geser setara dengan $1,439 \times 104 \mathrm{~kg} / \mathrm{m}^{2}$ dan 7,202 kg/m²tegangan geser.

Table 1. data hasil analisis struktur bangunan greenhouse

\begin{tabular}{|l|l|l|l|l|l|l|}
\hline No & Struktur & $\begin{array}{l}\text { Hasil } \\
\text { Perhitungan }\end{array}$ & $\begin{array}{l}\text { Nilai yang } \\
\text { diijinkan }\end{array}$ & Satuan & Sumber & Ket. \\
\hline 1 & Atap & & & & & \\
\hline & Tegangantarik & $0,001 \times 10^{6}$ & $1,880 \times 10^{6}$ & $\mathrm{Kg} / \mathrm{m}^{2}$ & Belis.et.all & Layak \\
\hline
\end{tabular}


Welis Raldianingrat dan Fitria, Kajian Model Desa Cerdas (Smart Village) berbasis Satu Desa Satu Greenhouse pada Wilayah Pusat Pertumbuhan Desa di Kabupaten Konawe

\begin{tabular}{|l|l|l|l|l|l|l|}
\hline & Lendutan & $0,002 \times 10^{-4}$ & $0,002 \times 10^{-4}$ & $\mathrm{~mm}$ & Belis.et.all & Layak \\
\hline 2 & Rangka Utama & & & & & \\
\hline & Lendutarahhorisontal & $0,013 \times 10^{-4}$ & $1.070 \times 10^{-4}$ & $\mathrm{~mm}$ & $\begin{array}{l}\text { Purnomo } \\
\text { dkk (2013) }\end{array}$ & Layak \\
\hline 3 & Lendutarahhorisontal & $0,023 \times 10^{-4}$ & $1.070 \times 10^{-4}$ & $\mathrm{~mm}$ & $\begin{array}{l}\text { Purnomo } \\
\text { dkk (2013) }\end{array}$ & Layak \\
\hline & DindingPlastik UV & & & & & Layak \\
\hline & Lendutan & $0,028 \times 10^{5}$ & $7,000 \times 10^{5}$ & $\mathrm{Kg} / \mathrm{m}^{2}$ & $\begin{array}{l}\text { ASTM } \\
\text { D790 }\end{array}$ & Layak \\
\hline
\end{tabular}

Sumber: Hasil Analisis

\section{Analisis Fungsional Greenhouse}

Analisis fungsional bangunangreenhouse dilakukan untuk mengetahuikondisi iklim mikro dalam menunjangbangunan menjalankan fungsinya secaraoptimal. Kesesuaian kondisi iklim di dalambangunan dapat berpengaruh terhadappertumbuhan dan produktivitas tanaman(Koesmaryono et al., 1997).

Pengambilan data iklim ini dilakukanuntuk mengetahui keadaan profil iklimmikro yang sebenarnya pada bangunandalam menjalankan fungsinya secara alami.Pengamatan dilakukan di dalam dan di luarbangunan selama 24 jam dengan parameteriklim yang diukur berupa radiasi matahari,suhu bola kering, kelembaban relatif, dankecepatan angin. Data hasil pengamatanyang didapatkan kemudian dikelompokkanke dalam 3 kondisi berbeda, yaitu padakondisi intensitas radiasi matahari (So) diatas 800 $\mathrm{W} / \mathrm{m} 2$, di antara 400-800 W/m2, dan di bawah $400 \mathrm{~W} / \mathrm{m} 2$. Profil iklim mikroyang terjadi pada penelitian dilakukan.

Secara keseluruhan dapat diketahuibahwa suhu di dalam bangunan relatif lebihtinggi dibandingkan dengan suhu di luarbangunan yang nilainya dipengaruhi olehintensitas radiasi matahari. Peningkatansuhu yang terjadi ini disebabkan karenaadanya kalor dari radiasi matahari yangmasuk ke dalam bangunan melalui atap dansebagian besarnya terjebak di dalambangunan (greenhouse effect).Perbedaansuhu di dalam dan di luar bangunan rata-ratapada pagi hari dapat mencapai $5^{\circ} \mathrm{C}$, padasiang hari sebesar $3^{\circ} \mathrm{C}$, dan pada malam harisebesar $1^{\circ} \mathrm{C}$. Suhu pada kondisi $\mathrm{S}_{\mathrm{o}}$ di atas $800 \mathrm{~W} / \mathrm{m}^{2}$ memiliki nilai yang relatif lebihtinggi dibandingkan pada kondisi $\mathrm{S}_{\mathrm{o}} 400-800 \mathrm{~W} / \mathrm{m}^{2}$ dan $\mathrm{S}_{\mathrm{o}}$ di bawah $400 \mathrm{~W} / \mathrm{m}^{2}$.

Profil iklim mikro menunjukkan adanya hubungan antara intensitas radiasimatahari, suhu, dan kelembaban udara.Kelembaban relatif dan kelembaban mutlakudara berbanding terbalik dengan suhu danS . $_{\text {. }}$ Dapat diketahui jika RH di luarbangunan lebih tinggi dibandingkan dengannilai RH di dalam bangunan karena suhu didalam bangunan lebih tinggi sehinggapenguapan uap air di dalam bangunanberlangsung lebih cepat.

Angin dan arah angin juga memilikipengaruh dalam proses perpindahan kalor didalam bangunan. Namun dalam hal ini didapatkan bahwa kecepatan angin yangmengenai bangunan relatif kecil yang nilaimaksimalnya hanya sebesar 1,01 m/s dariarah Timur ke Barat. Meskipun arah aliranangin sama dengan bukaan ventilatorkecepatan angin di dalam bangunan sangatkecil bahkan tidak ada.

Hasil pengamatan yang dilakukanmenunjukkan bahwa nilai $\mathrm{T}_{\mathrm{dbi}}$ rata-rata sebesar $28^{\circ} \mathrm{C}$ dengan suhu tertinggi terdapat pada pagihari yaitu $31^{\circ} \mathrm{C}$ dan suhu terendah $20^{\circ} \mathrm{C}$.Menurut Wiryanta (2002), suhu optimumuntuk fase vegetatif pada tahapanpertumbuhan dan masa awal pembungaantanaman tomat adalah $25^{\circ}-30^{\circ} \mathrm{C}$ padasiang hari dan $16^{\circ}-20^{\circ} \mathrm{C}$ pada malam hari.

Dapat disimpulkan bahwa kondisi iklim mikrountuk pertumbuhan dan perkembangantanaman tomat sudah cukup optimaluntuk fase vegetatif meskipun masih terdapatkondisi suhu di atas kondisi optimal. Namunjika tanaman sudah memasuki fase generatifkondisi iklim mikro sudah tidak memenuhisyarat 
Welis Raldianingrat dan Fitria, Kajian Model Desa Cerdas (Smart Village) berbasis Satu Desa Satu Greenhouse pada Wilayah Pusat Pertumbuhan Desa di Kabupaten Konawe

optimal untuk tanaman tomat yang seharusnya suhu di dalam bangunansebesar $24^{\circ}-28^{\circ} \mathrm{C}$ dan $18^{\circ}-24^{\circ} \mathrm{C}$ untuk tahapanpembentukan buah optimal.

Data hasil pengamatan yang dilakukanmenunjukkan nilai RHi rata-rata tertinggimencapai $90 \%$ yang terjadi pada malam hari.Sedangkan kondisi $\mathrm{RH}_{\mathrm{i}}$ pada pagi dan sianghari secara berurutan sebesar $59 \%$ dan 69\%.Menurut Rubatzky and Yamaguchi (1999),syarat optimal kelembaban relatif udara untuktomat sebesar $80 \%$ dan tidak bolehmelebihi $95 \%$. Hal ini menunjukkan bahwakondisi $\mathrm{RH}_{\mathrm{i}}$ di dalam bangunan belummemenuhi syarat optimal yang dibutuhkantanaman.

\section{Aspek Finansial}

\section{Biaya Konstruksi Greenhouse}

Investasi yang dibutuhkan untuk berusaha tani adalah sebesarRp. 337.030.630,- (tiga ratus tiga puluh tujuh juta tiga puluh ribu enam ratus tiga puluh rupiah). Digunakan untuk biaya tetap yaitu pembangunan greenhouse dan peralatan, serta biaya variabel.

\section{BiayaTetap dan Variabel}

Biaya-biaya yang dikeluarkan adalah termasuk biaya tetap dan biaya variabel. Untuk biaya tetap sebesar Rp. 326.360.360,- dan biaya variabel sebesar Rp. 10.400.000,-. Biaya tetap ini digunakan untuk pembelian alat usaha tani dan pembangunan greenhouse, sedangkan total biaya penyusutan sebesar Rp. 14.954.233 dengan penyusutan dalam setahun sebesar Rp. 829.547,-

\section{Hasil AnalisisKelayakanFinansialInvestasi Greenhouse}

\section{Hasil AnalisisSkenarioRendah}

Perhitungan kelayakan financial usaha ini diperoleh dari data hasil pengurangan penerimaan dengan biaya. Adapun hasil perhitungan kelayakan usaha tani tomat adalah sebagai berikut :

Hasil perhitungan dari criteria kelayakan investasi yang meliputi NPV, IRR, dan Net B/C Ratio, diperoleh dari hasil pengurangan penerimaan dengan biaya. Sedangkan untuk perhitungan payback period didasarkan pada data cash flow sehingga payback period tidak dijadikan sebagai hasil untuk menentukan layak atau tidaknya usaha tani, akan tetapi hanya digunakan sebagai waktu pengembalian investasi.

\section{Net Present Value}

Hasil NPV sebesar Rp.316.966.303,- juta yang berarti usaha tani ini akan menerima keuntungan sebesar Rp. 316.966.303,- selama 5 Tahun menurut nilai waktu uang sekarang. Nilai IRR adalah sebesar $58,82 \%$ yang berarti lebih besar dari suku bunga biaya tetap $10 \%$. Sehingga usaha budidaya tomat ini layak diusahakan. Net Present Value (NPV) menunjukkan nilai kini manfaat bersih yang diperoleh selama periode usaha sebesar Rp.316.966.303,- $(N P V>0$.

\section{Net Benefit-Cost Ratio (Net B/C)}

Nilai Net B/C Ratio sebesar 2,91 yang artinya bahwa setiap Rp.1,- biaya yang dikeluarkan, akan memeberikan keuntungan sebesar Rp.1,91 rupiah. Net Benefit-Cost Ratio (Net B/C) adalah rasio antara manfaat bersih yang menguntungkan usaha dengan manfaat bersih yang merugikan usaha. Nilai $\mathrm{Net} B / \mathrm{C}$ sebesar 2,91 menunjukkan tambahan manfaat bersih yang diperolehakan bertambah sebesar sebesarRp 2.910 setiap penambahan biaya sebesarRp 1.000. Nilai $\mathrm{Net} B / C$ lebih besar dari satu artinya setiap penambahan biaya pada usaha budidaya akan menghasilkan manfaat yang lebih besar dari biaya yang ditambahkan. Berdasarkan analisis Net $B / C$ maka usaha budidaya tomat layak untuk dijalankan.

\section{Internal Rate of Return (IRR)}

Analisis $I R R$ untuk melihat seberapa besar pengembalian usaha terhadap investasi yang ditanamkan. $I R R$ menunjukkan tingkat suku bunga yang menghasilkan $N P V$ sama dengan nol dengan satuan persentase. Kriteria kelayakan dilakukan dengan membandingkan nilai $I R R$ dengan tingkat suku bunga yang digunakan. Berdasarkan nilai $I R R$ sebesar 58.82 persen artinya tingkat pengembalian usaha budidaya tomat terhadap investasi yang ditanamkan sebesar 58.82 persen. Nilai $I R R$ yang diperoleh lebih besar dibandingkan dengan nilai suku bunga yang digunakan sebesar $11 \%$, sehingga usaha budidaya tomat layak untukdiusahakan.

\section{Analisis Payback Period (PP)}

Analisis payback period mengukur seberapa cepat pengembalian investasi pada suatu usaha. Payback period terjadi pada tahun ke-5 atau panen ke-12. Saat tahun ke-5 pengembalian investasi dari usaha 
Welis Raldianingrat dan Fitria, Kajian Model Desa Cerdas (Smart Village) berbasis Satu Desa Satu Greenhouse pada Wilayah Pusat Pertumbuhan Desa di Kabupaten Konawe

budidaya tomat mencapai titik impasnya. Berdasarkan criteria investasi payback period masih dalam umur proyek, sehingga usaha ini layak untuk diusahakan.

Hasil analisis kelayakan financial menunjukkan bahwa usaha budidaya tomat layak untuk diusahakan. Kriteria investasi menunjukan NPVRp.316.966.303,- $(N P V>0,2,91>1$, dan $I R R 58,82 \%>D R$ $11 \%$, dan payback period tahun ke-5 masih dalam umur proyek 5 tahun. Hasil ini menunjukkan bahwa usaha budidaya tomat secara ekonomi menjanjikan keuntungan. Selain keuntungan finansial yang akan didapatkan dari usaha budidaya tomat ini, ada berbagai keuntungan lainnya seperti terjaminnya suplai tomat untuk industry pengolahan tomat dan pasar tomat, meningkatkan kualitas tomat, menunjang industry pengolahan tomat dengan tersedianya tomat berkualitas dan sesuai spesifikasi pasar, serta member dampak ekonomi bagi masyarakat sekitar.

\section{Analisis Sensitivitas Skenario Rendah}

Hasil perhitungan dari criteria kelayakan investasi yang meliputi NPV, IRR, dan Net B/C Ratio, diperoleh dari hasil pengurangan penerimaan dengan biaya. Sedangkan untuk perhitungan payback period didasarkan pada data sensivitas sehingga payback period tidak dijadikan sebagai hasil untuk menentukan layak atau tidaknya usaha tani, akan tetapi hanya digunakan sebagai waktu pengembalian investasi, adapun hasil analisis terdapat pada tabel5.25.

Tabel 2. Hasil Analisis Sensivitas jika Biaya Operasional Meningkat 6\%

\begin{tabular}{|l|l|l|l|l|}
\hline No & AlatAnalisis & Hasil Analisis & Indikatorkelayakan & Keterangan \\
\hline 1 & Net Present Value (NPV) & Rp. 153.812.143 & NVP $>0$ & Layak \\
\hline 2 & Internal Rate of Return (IRR) & $26,38 \%$ & IRR $>$ DR & Layak \\
\hline 3 & $\begin{array}{l}\text { Net Benefit Cost Ratio (Net } \\
\text { B/C) }\end{array}$ & 1.47 & Net B/C $>1$ & Layak \\
\hline 4 & Payback Period & 5 Tahun & & Layak \\
\hline
\end{tabular}

Hasil NPV sebesar Rp.153.812.143,- juta yang berarti usaha tani ini akan menerima keuntungan sebesar Rp. 153.812.143,- juta selama 5 Tahun menurut nilai waktu uang sekarang. Nilai IRR adalah sebesar $26,38 \%$ jika suku bunga biaya operasional naik 6\%. Sehingga usaha budidaya tomat ini layak diusahakan.

\section{Aspek Kebijakan}

\section{Kebijakan Pembangunan Desa di Kecamatan OnembuteKabupatenKonawe}

Sesuai dengan amanat UU No. 6 Tahun 2014 tentang Desa, tujuan pembangunan desa adalah meningkatkan kesejahteraan masyarakat desa dan kualitas hidup manusia serta penanggulangan kemiskinan melalui pemenuhan kebutuhan dasar, pembangunan sarana dan prasarana desa, membangun potensi ekonomi lokal, serta pemanfaatan sumber daya alam dan lingkungan secara berkelanjutan. Oleh karena itu, pada periode tahun 2016-2022, rencana pembangunan jangka menengah desa diarahkan untuk peningkatan aparatur pemerintah desa dan BPD, penguatan peran dan fungsi kelembagaan kemasyarakatan, serta penguatan masyarakat desa. Disamping itu, pembangunan diarahkan pada pengembangan pusat-pusat pertumbuhan untuk mendorong pengembangan perdesaan berkelanjutan yang memiliki ketahanan sosial, ekonomi, dan ekologi sertamen dorong keterkaitan desa-kota

\section{Model Kebijakan Pembangunan Desa Cerdas (Smart Village)}

Model kebijakan pembangunan Desa Cerdas merupakan dasar kebijakan pembangunan pedesaan yang berorientasi pada basis sectoral (pengembangan sector basis). Oleh karena itu dibutuhkan suatu implementasi kebijakan

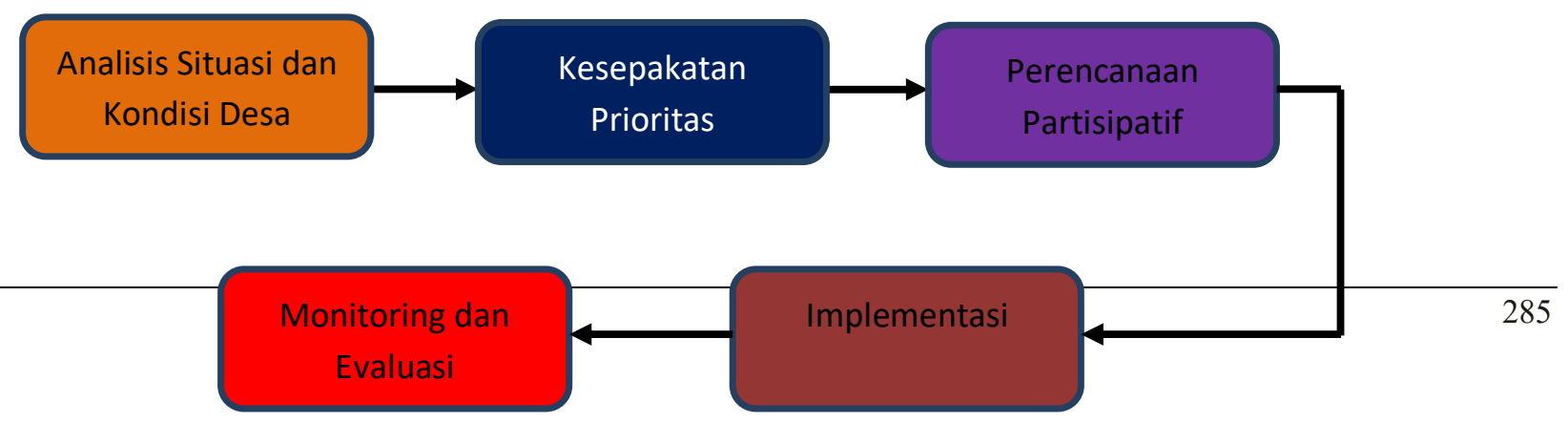


Welis Raldianingrat dan Fitria, Kajian Model Desa Cerdas (Smart Village) berbasis Satu Desa Satu Greenhouse pada Wilayah Pusat Pertumbuhan Desa di Kabupaten Konawe

\section{Gambar 2. Model Kebijakan Pembangunan Desa Cerdas}

\section{Analisis Situasional dan Kondisi Desa Kecamatan Onembute Kabupaten Konawe}

Analisis ini melibatkan setiap elemen dalam organisasi, pihak yang terlibat, kegiatan strategi dan taktik yang akan diambil, serta anggaran biaya yang perlu dikeluarkan dalam program program desa cerdas (satu desa satu greenhouse). Singkatnya, Analisis Situasi merupakan cara, metode, langkah dan persiapan yang dilakukan untuk memecahkan masalah yang sedang atau telah terjadi, sebagai penghambat perkembangan dan perjalanan sebuah organisasi dalam mewujudkan visi, misi serta tujuannya program desa cerdas (satu desa satu greenhouse). Proses analisis ini dibedakan menjadi 2 macam, yakni Analisis Internal dan Analisis Eksternal.

\section{Analisa Internal}

Merupakan kegiatan dalam meninjau kembali semua persepsi dan tindakan dalam organisasi, antara lain adalah hubungan individu, kunci informasi dan badan pengawas terhadap program desa cerdas (satu desa satu greenhouse). Analisa ini ditujukan untuk mengidentifikasi bentuk kinerja dan kegiatan yang bersifat strategis. Analisis Internal ini akan berkaitan dengan Sumber Daya yang ada di organisasi seperti Sumberdaya Manusia, Modal dan Sumberdaya lainnya terkait program desa cerdas (satu desa satu greenhouse).

\section{Analisa Eksternal}

Adalah kegiatan peninjauan ulang terhadap penyebab yang berasal dari luar organisasi atau organisasi. Cakupannya adalah Studi Pustaka, Survei, pengamatan dan analisisisi.

\section{Analisis Situasional Program desa cerdas (satu desa satu greenhouse)}

Untuk menjalankan penganalisisan ini, ada beberapa langkah yang sekiranya patut untuk diperhatikan, mulai dari Mengidentifikasi masalah program desa cerdas (satu desa satu greenhouse), merincikan atau memprioritaskan, hingga memulai memecahkan masalah. Tiga langkah ini harus dilakukan seoptimal mungkin dalam upaya tercapainya tujuan dan hasil yang maksimal.

\section{Mengidentifikasi Masalah program desa cerdas (satu desa satu greenhouse)}

Masalah yang terlanjur muncul pasti ada sebab yang jadi pemancing dan akibat yang dihasilkan (sebab-akibat). Umumnya, masalah datang karena rasa ketidak puasan suatu hal, masalah kecil atau besar baik dari dalam maupun luar organisasi.Untuk mengidentifikasinya, kita bisa memakaimetode Stair Stepping atau Anak Tangga Permasalahan. Menurut pengalaman pengguna, metode ini bisa merumuskan masalah hingga keakarnya. Untuk menemukan akar masalah yang lebih mendalam, diperlukan penggalian informasi tambahan dari pihak yang bersangkutan soal pokok masalah yang ada. Salah satu cara adalah dengan melakukan wawancara langsung dengan pihak terkait, yang perlu dilakukan pertama adalah mengidentifikasi masalah apa yang paling menonjol dan menimbulkan efek paling jelas program desa cerdas (satu desa satu greenhouse), dan prioritaskan masalah tersebut hingga tuntas. Setelah informasi dirasa lengkap dan terpecahkan, barulah melakukan riset terhadap persoalan lainnya yang lebih keci lterkait program desa cerdas (satu desa satu greenhouse)

\section{Merelokasikan Masalah menjadi Tugas dalam program desa cerdas (satu desa satu greenhouse)}

Setelah berhasil mengidentifikasi dan merincikan masalah, sekarang saatnya menempatkan posisi masalah menjadi "Hal Penting" dalam organisasi desa agar segera dipecahkan. Artinya, organisasi desa harus memprioritaskan maslaah tersebut supaya pengaruhnya tidak berdampak lebih besar lagi. Manajemen Organisasi harus segera menunjuk orang atau kelompok untuk membentuk tim khusus sebagai bagian dari organisasi yang bertugas memecahkan masalah yang ada program desa cerdas (satu desa satu greenhouse). Orang-orang yang diangkat bisa dipilih dari luar organisasi maupun pihak dari dalam.

Pemecahan Masalah program desa cerdas (satu desa satu greenhouse) 


\section{Welis Raldianingrat dan Fitria, Kajian Model Desa Cerdas (Smart Village) berbasis Satu Desa Satu Greenhouse pada Wilayah Pusat Pertumbuhan Desa di Kabupaten Konawe}

Setelah yakin dengan hasil data yang dikumpulkan dan merelokasian masalah program desa cerdas (satu desa satu greenhouse), saatnya untuk melakukan pemecahan. Pada tahap ini, pihak yang bertanggung jawab harus memperhatikan dengan seksama terkait segala faktor yang ada. Yang pertama adalah hasil penggalian secara mendalam yang didapat dari hasil wawancara, kotak saran dan kegiatan terjun kelapangan yang dilakukan jauh hari. Data tersebutakan diolah dan dirumuskan sesuai kaidah organisasi.

\section{SIMPULAN}

Berdasarkan hasil analisis dan pembahasan pada bab sebelumya maka peneliti menarik kesimpulan sebagai berikut

1. Desain Greenhouse berbentuk tunnel dengan system klem memberikan keuntungan dari segi kekuatan struktur dengan tingkat pembuatan yang mudah dikerjakan oleh siap asaja. Desain greenhouse sistem tunnel mampu memberikan kemudahan pada control terhadap suhu udara sehingga memberikan dampak positif terhadap control produksi tanaman terutama pada wilayah Kecamatan Onembute

2. Hasil perbandingan keuntungan ekonomi berupa Analisa sensitifitas produksi dan biaya menunjukkan bahwa Hasil NPV sebesarRp. 326.545.587,- yang berarti usaha tani ini akan menerima keuntungan sebesar Rp.326.545.587,- selama 5 Tahun menurut nilai waktu uang sekarang dengan asumsi scenario rendah yang berarti usaha tani dilakukan tanpa teknologi Greenhouse. Sedangkan Hasil Analisa sensitifitas scenario tinggi produksi dan biaya menunjukkanbahwa Hasil NPV sebesar Rp. 476.887.391,yang berarti usaha tani ini akan menerima keuntungans ebesarRp. 476.887.391,-hanya dalam jangka 1 Tahun menurut nilai waktu uang sekarang dengan asumsi usaha tani dilakukan denganmenggunakan teknologi Greenhouse.

3. Model kebijakan yang dapat diterapkan dalam mendukung kebijakan Desa Cerdas berbasis satu desasatu greenhouse pada Kecamatan Onembute adalah model kebijakan elit dimana Kepala Desa memiliki kewenangan dalam keputusan investasi Greenhouse untukusaha produktif dan kreatif pedesaan.

\section{DAFTAR PUSTAKA}

Abdul, Halim. 2003. Analisis Investasi. Salemba Empat. Jakarta.

Clive, Gray dan Payaman Simanjuntak. 2005. Pengantar Evaluasi Proyek. Gramedia. Jakarta.

Gay, L.R. dan Diehl, P.L. 1992. Research Methods for Business and Management. Mac Milan Publishing Company. New York.

Gittinger, JP. 1986. Analisa Ekonomi Proyek-Proyek Pertanian. Penerjemah

Slamet Sutomo dan Komet Mangiri. Penerbit Universitas Indonesia. Jakarta.

Ibrahim, Yacob. 2003. Studi Kelayakan Bisnis. Edisi Revisi Rineka Cipta. Jakarta.

Kadariah, K.L, dan Gray C. 1999. Pengantar Evaluasi Proyek. Fakultas Ekonomi

Universitas Indonesia. Jakarta.

Kasmir dan Jakfar. 2003. Studi Kelayakan Bisnis. Kencana. Jakarta.

Munawir. 1995. Analisis Laporan Keuangan. Edisi 4. BPFE. Yogyakarta.

Nitisemito, Alex S. dan M. Umar Burhan. 2009. Wawasan Studi Kelayakan dan Evaluasi Proyek. Edisi Revisi. Cetakan Kedua. Bumi Aksara. Jakarta.

Siswandi, 2009. Aplikasi Manajemen Hukum dan Perusahaan, Jakarta, Mitra wicana media.

Soeharto, I. 2001. Studi Kelayakan Proyek Industri. Penerbit Erlangga. Jakarta.

Sukirno, Sadono. 2003. Pengantar Teori Ekonomi Mikro. Penerbit PT. Salemba.

Jakarta.

Sugiyono. 2010. Metode Penelitian Pendidikan Pendekatan Kuantitatif, Kualitatif dan R\&D. Alfabeta. Bandung.

Suratman. 2001. Studi Kelayakan Proyek. J\&J Learning. Yogyakarta.

Tamin.1997. Pemodelan Transportasi. ITB press. Bandung

Umar, Husein. 2003. Riset pemasaran dan Perilaku Konsumen. PT. Gramedia Pustaka Utama. Jakarta. 
Welis Raldianingrat dan Fitria, Kajian Model Desa Cerdas (Smart Village) berbasis Satu Desa Satu Greenhouse pada Wilayah Pusat Pertumbuhan Desa di Kabupaten Konawe

Umar, Husein. 2005. Studi Kelayakan Bisnis, Manajemen, Metode dan Kasus. PT Gramedia Pustaka Utama. Jakarta.

Weston, Fred, J dan Brigham, F, Eugene. 1990. Dasar-dasar Manajemen Keuangan. Edisi Kesembilan. Penerbit Erlangga. Jakarta. 